Journal of Advanced College of Engineering and Management, Vol. 6, 2021

\title{
URBAN ENERGY SCENARIO OF HOUSEHOLD SECTOR IN BHAKTAPUR MUNICIPALITY FOR SUSTAINABLE ENERGY DEVELOPMENT
}

\author{
Raj Kumar KC ${ }^{1}$, Amrit Man Nakarmi ${ }^{2}$ \\ 1, 2 Department of Mechanical Engineering, Pulchowk Campus, Institute of Engineering, \\ Tribhuvan University, Nepal \\ Email Address: nea.rajkc2073@gmail.com,_nakarmiamrit@ioe.edu.np
}

\begin{abstract}
This study aims to analyseenergy scenarios of Bhaktapur Municipality through primary data survey of 165 houses as a function of household's characteristics. Three scenarios are considered business-as-usual(BAU),Sustainable Energy scenario(SED) and Accelerated Growth Scenario(AGS). BAU, SED and AGS show an expected energy growth at annual rates of $4.08 \%, 3.71 \%$ and $4.01 \%$; with economic growth of $4.6 \%, 7.0 \%$ and $9.2 \%$ respectively. Whereas, the electricity consumption per household in the SEDand AGS are 3,840KWh and 4,698KWh respectively, lies in tier-5 as per SDG. Fuel imported cost NRs. 471 million and NRs. 523 million can be saved in SED and AGS Scenarios respectively as compare to BAU scenario. Overall, under all three scenarios, it was found that total GHG emission in 2018 was 7.59 kilotons to nil in 2030 for SED and AGS.Furthermore,NPV value in AGS and SED scenarios are in negative value which means both scenarios is economically viable.
\end{abstract}

Keywords: Demand, Household characteristic, GHG emission, NPV

\section{Introduction}

Energy is a crucial enabler for sustainable growth of economy, social development and for improving the quality of life. Household sector mainly urbanization plays key role in what has become known as "energy transition" from traditional sources to modern forms of fuels [1], with major influencing drivers - income, energy access, and energy prices [2]. It is generally accepted that economic growth promotes the expansion of modern industries and an increase in the urban population; in turn, urbanization also promotes economic growth to some extent. Though, in context of Nepal, transition to modern fuel is driven by imported fossil fuels, which has increase concern of energy security as well as increasing trade deficit of country. In 2014, the level of urbanization was 18.2 per cent, with an urban population of 5,130,000, and a rate of urbanization of 3 per cent [3].Further, unplanned urbanization has raise concern in policy formulation for sustainable development particularly in Kathmandu valley.

\subsection{Problem Statement}

Rapid urbanization has resulted in consumption of modern energy which is driven by imported fossil fuels and it indicates an unsustainable trend with poor harnessing of indigenous renewable energy. Additionally, unrestrained urbanization, cost ineffective, inefficient, conventional technology driven energy consumption has cause further increase in concern of sustainable energy consumption.

\subsection{Objectives}

The main objective of the study is to develop future household energy scenario with sustainable energy development and energy security of Bhaktapur Municipality from 2018 to 2050. 


\section{Literature Review}

\subsection{Brief Description of Bhaktapur Municipality}

Bhaktapur is a mid-sized municipality located $12 \mathrm{~km}$ East of Kathmandu Metropolitan City in Province 3. It is the third largest city in Kathmandu Valley occupying an area of $6.88 \mathrm{Sq}$. Km and divided into 10 Wards. It is a township of unique culture with complex society. It was once the capital of Nepal during the reign of great Mall dynasty. Bhaktapur Municipality was established on $24^{\text {th }}$ March, 2006 [4].Fig. 1 shows map of Bhaktapur Municipality .

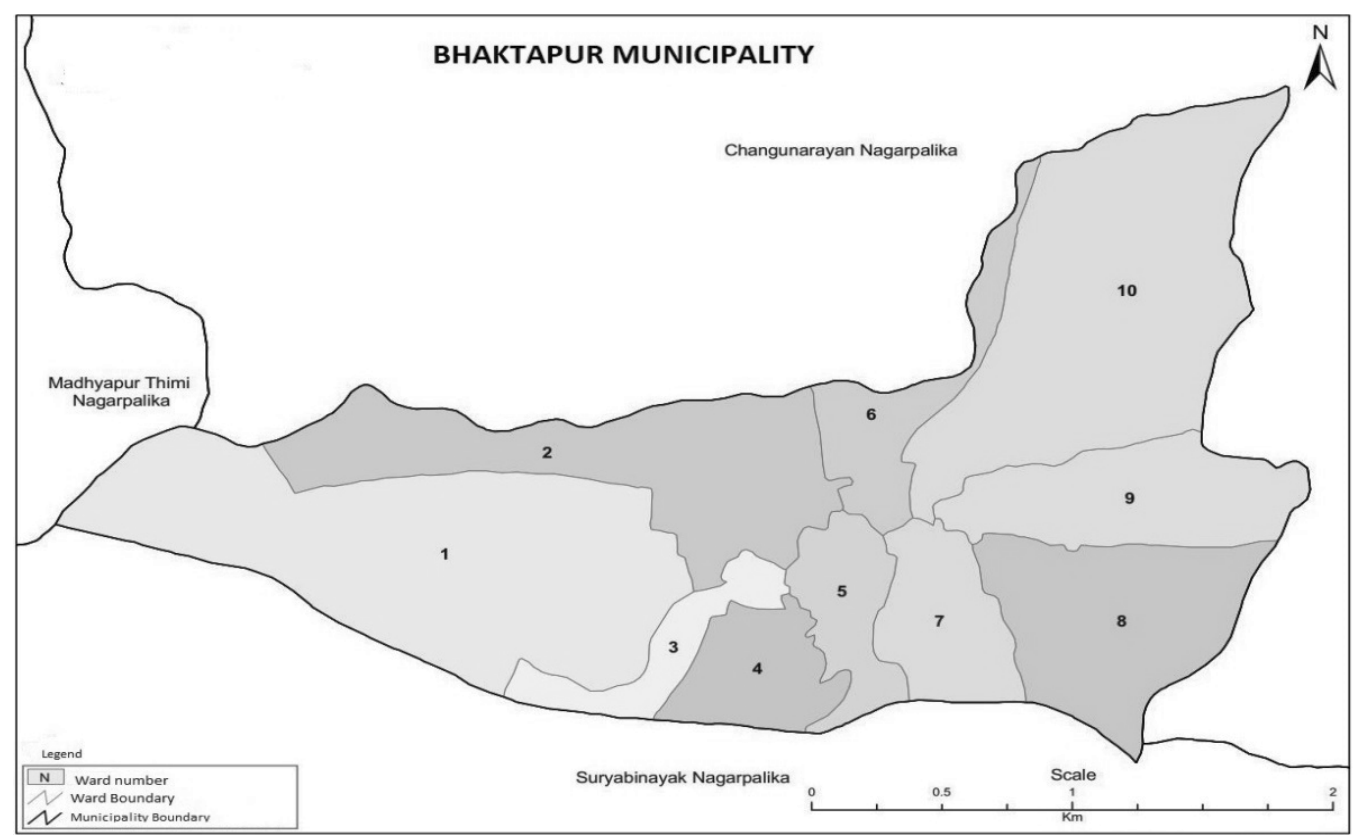

Fig 1 Bhaktapur Municipality

\subsection{Gap}

A study conducted by [5]found that the total energy consumption of residential sector of Dhulikhel Municipality $72 \mathrm{TJ}$ per year and the energy consumption in rural area higher than the energy consumption in urban area of Dhulikhel Municipality this is due to the use of inefficient technologies like biomass cook stoves. In paper [3], Bhattarai projects demand for each sector by taking the data from different sources. The District Climate and Energy Plan of Bhaktapur sub metropolitan [6], Energy needs of the district was determined on the bases of rural and urban area. In Paper by Rajbhandari \& Nakarmi[7], Kathmandu was taken as study area and it was shown that with optimization energy demand reduction by $27 \%$ was possible. Furthermore, Biswambhar Panthi [8] analyzed Residential Sector Energy consumption, projection of energy demand and emission analysis under different scenarios.

Similarly, many other studies are undertaken in the field of energy analysis yet study focusing on relation of GDP and energy consumption in different sector, consumption pattern, emission, human behavior, energy security and costing at Municipality level are rare which is attempted in this study taking in the case of urbanized municipality of the country. 


\section{Research Methodology}

The methodology followed for doing the study can be understood from the flowchart drawn and the explanations followed. Fig. 2 shows methodological flow chart.

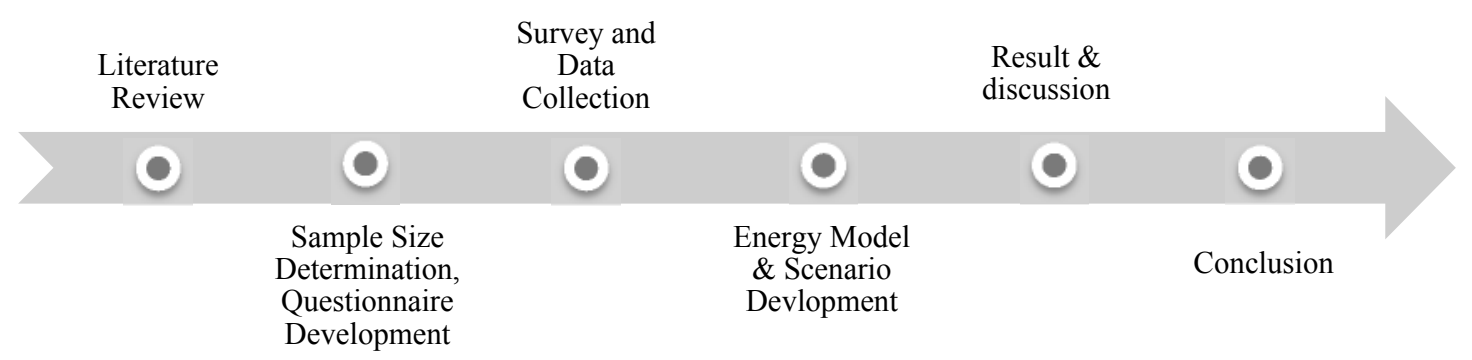

Fig 2 Flow Chart for methodology adopted

Total of 200 energy related data were gathered through questionnaire survey. The sample size was calculated using the following equation [9]:

$$
S=\frac{X^{2} N P(1-P)}{d^{2}(N-1)+X^{2} P(1-P)}
$$

Where,

$\mathrm{S}=$ required sample size

$\mathrm{X}^{2}=$ table value of chi-square for 1 degree of freedom at the desired confidence level

$\mathrm{N}=$ population size

$\mathrm{P}=$ population proportion

$\mathrm{d}=$ the degree of accuracy expressed as a proportion.

\subsection{Questionnaire Development}

This research primarily utilizes the survey based method that concentrates on household energy use patterns in Bhaktapur Municipality. The questionnaire sought to collect data on residential energy consumption, which was disaggregated into 7 energy services to identify the end-use patterns at the time of the survey. In order to understand the energy consumption and energy usage behavior of households of urban residential sector in a holistic way, the survey is designed with content and coverage area as shown in Fig. 3.

\subsection{Service demand projections}

Estimationoffuturelevelsofenergydemandinthisstudyisbasedonapproach:using population and GDP per capita for estimation of service demands in the residential sectors. The estimation of service demands in the residential sector is based on the following relationship:

$$
\mathrm{SDi}, \mathrm{t}=\mathrm{SDi}, 0 \times\left(\frac{\mathrm{POPt}}{\mathrm{POPo}}\right)^{\alpha \mathrm{i}} \times\left(\frac{\mathrm{GDPt}}{\mathrm{GDPo}}\right)^{\beta \mathrm{i}}
$$




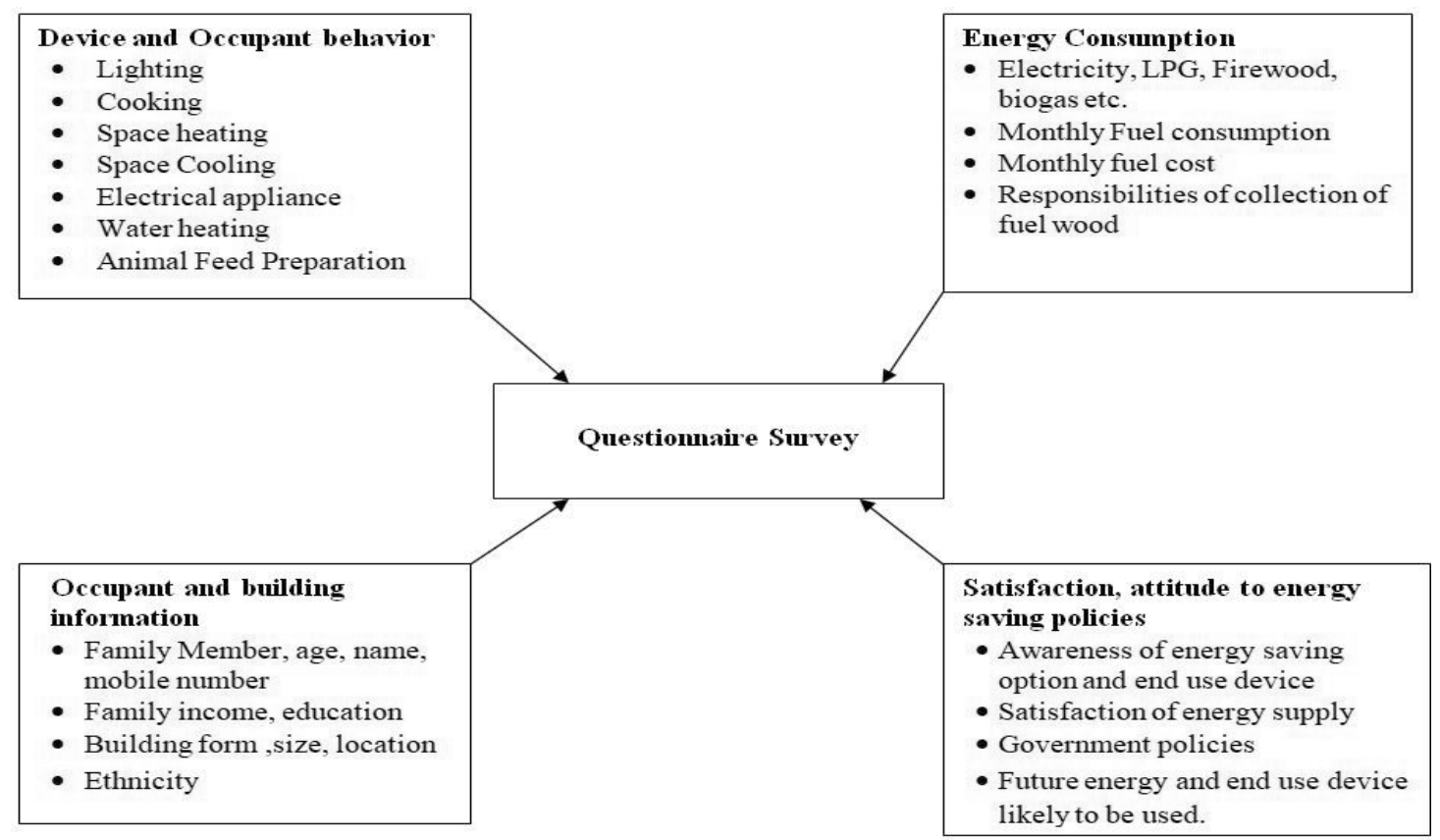

Fig 3 Questionnaire Survey Content \& Coverage Area

Here,

$\mathrm{SDi}, \mathrm{t}$ and $\mathrm{SDi}, 0=$ service demand of sub sector $\mathrm{I}$ in year $\mathrm{t}$ and the base year respectively.

POPt and POP0 = population of the municipality in year $t$ and the base year respectively.

$\alpha i$ and $\beta i=$ population and GDP elasticities of service demand of sub sector i respectively.

The values of services demand elasticities are used from the study by [11] which are estimated from regressions analysis using population and GDP as in dependent variables and service demand as dependent variables. The values of population GDP elasticities are shown in Table 1

\begin{tabular}{|l|c|c|}
\hline \multirow{2}{*}{ Residential End-Use } & \multicolumn{2}{|c|}{ Elasticity } \\
\cline { 2 - 3 } & Population & GDP \\
\hline Space heating & 2.33 & 0.26 \\
\hline Space cooling & 2.33 & 0.26 \\
\hline Electrical appliances & 2.33 & 0.26 \\
\hline Cooking & 0.99 & 0.031 \\
\hline Lighting & 0.99 & 0.031 \\
\hline Water heating & 0.99 & 0.031 \\
\hline Other & 0.99 & 0.031 \\
\hline
\end{tabular}

Table 1 Elasticity value of end-uses

\section{Scenarios Description}

Scenario planning is a useful approach to design and plan long term future energy demand and supply requirements. For the scenario analysis, 2018 was taken as a base year. The future final energy demandofBhaktapurMunicipalitywasprojectedtotheyear2050.PopulationandGDP are the key drivers of the residential energy demand. Table 2 shows simple comparative study of all three scenarios. 


\begin{tabular}{|c|c|c|}
\hline \multicolumn{2}{|c|}{ Scenario name } & Descr \\
\hline BAU & $\begin{array}{l}\text { Bus } \\
\text { usual }\end{array}$ & $\begin{array}{l}\text { - Population growth rate } 1.43 \% \& \text { Per capita Income growth rate } \\
4.6 \% \text {,based on the value of average of economic growth rate } \\
\text { of Asia \& Pacific countries from } 2007 / 08 \text { to } 2016 / 18 \text { [12] } \\
\text { - Energy intensities and energy mix remains constant. }\end{array}$ \\
\hline SED & $\begin{array}{l}\text { Sustainable } \\
\text { Energy } \\
\text { Development } \\
\text { Scenario }\end{array}$ & $\begin{array}{l}\text { - Population growth rate }=1.43 \% \& \text { Per capita income growth } \\
\text { rate }=7.0 \% \text { based on the average economic of South Asian } \\
\text { and pacific countries [12]. } \\
\text { - Population rate remains constant throughout the study period. } \\
\text { - Traditional energy sources like fuel-wood gradually replaced } \\
\text { by clean and modern source. } \\
\text { - Make energy consumption achieve to tier-5 "Beyond } \\
\text { Connection: Energy Access Redefined". }\end{array}$ \\
\hline AGS & $\begin{array}{l}\text { Accelerated } \\
\text { Growth } \\
\text { Scenario }\end{array}$ & $\begin{array}{l}\text { - Population growth rate }=1.43 \% \text { \& Per Capita income growth } \\
\text { rate }=9.2 \% \text { used based on the average GDP growth rates of the } \\
\text { countries like Bhutan, Ethiopia, Ghana, India, Myanmar [12]. } \\
\text { - Gradual phase out of traditional and fossil fuel by clean source } \\
\text { of energy like electricity by } 80 \% \text { and solar by } 20 \% \text { the year } \\
2025 \text { and by the year } 2040 \text { by electricity } 50 \% \text { and solar } 50 \% \text {. } \\
\text { - Make comparable energy consumption to achieve target of } \\
1,000 \mathrm{kWh} \text { per capita till } 2040 \text {, to reach corresponding to an } \\
\text { HDI of } 0.8 \text {. }\end{array}$ \\
\hline
\end{tabular}

Table 2 Scenario Summaries

\section{Results and discussions}

\subsection{Energy Demand for Base year (2018)}
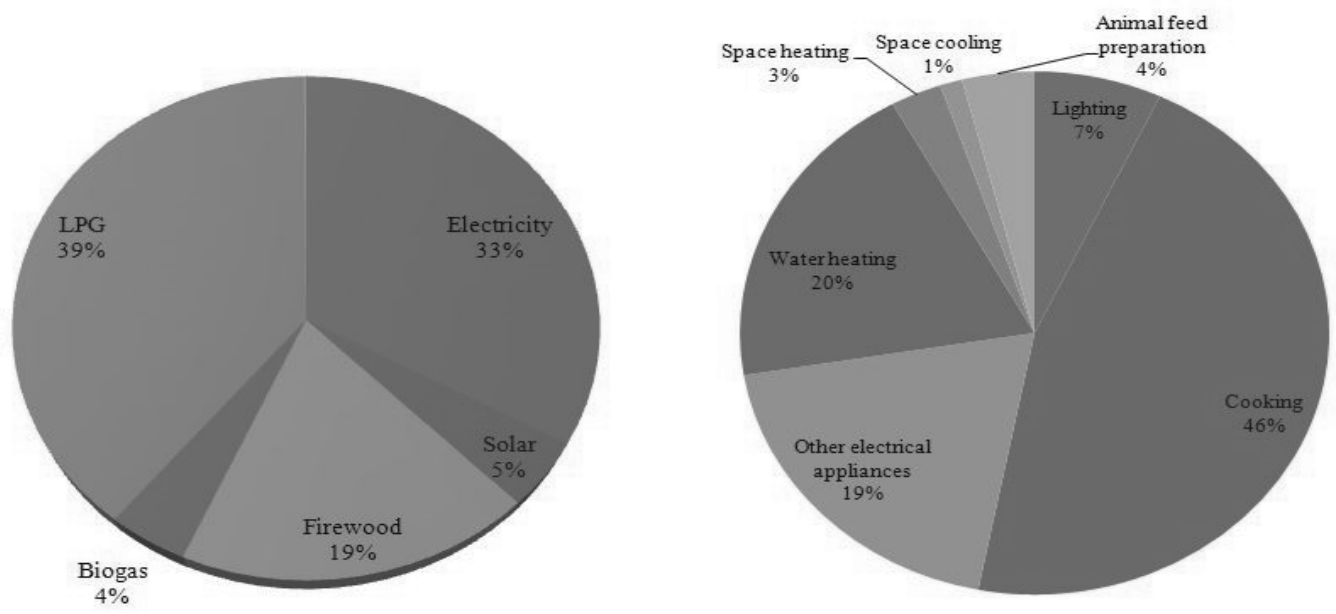

Fig. 4 Final energy demand share by endues

Fig. 5 Final energy demand share by fuel type

Energy demand of residential sector of Bhaktapur Municipality is 294.99 TJ in the year 2018 accounting 3.28 GJ per capita. Fig. 4 shows the share of final energy demand by fuel type in 2018 . It seen that the total energy share was dominated by petroleum products $(39 \%)$. Modern renewables like electricity, solar accounts for about $38 \%$ of total share while traditional renewables also has noticeable share. Fossil fuel was primarily used for cooking and heating purpose meanwhile electricity was chiefly used for electrical appliances, cooking and lighting. 
Fig. 5 shows the final energy demand by endues types in 2018. It is seen that cooking was the dominant endues which accounts for $48 \%$ of total energy demand. It is followed by electrical energy consumption by water heating (20\%), electrical appliances (19\%), lighting (7\%) and room heating (3\%). Fuel-wise demand for each end use is presented in Table 3.

\begin{tabular}{|l|l|l|l|l|l|l|l|}
\hline Enduse/Fuels & Electricity & Solar & Firewood & Biogas & LPG & Briquette & $\begin{array}{l}\text { Total } \\
\text { (TJ/Year })\end{array}$ \\
\hline Lighting & 20.42 & 0.22 & 0 & 0 & 0 & 0 & $\mathbf{2 0 . 6 3}$ \\
\hline Cooking & 9.64 & 0.00 & 27.97 & 9.74 & 88.32 & 0.28 & $\mathbf{1 3 5 . 9 4}$ \\
\hline $\begin{array}{l}\text { Other } \\
\text { electrical } \\
\text { appliances }\end{array}$ & 57.06 & 0.00 & 0.00 & 0.00 & 0.00 & 0.00 & $\mathbf{5 7 . 0 6}$ \\
\hline Water heating & 1.64 & 13.13 & 13.45 & 2.92 & 26.49 & 0.08 & $\mathbf{5 7 . 7 3}$ \\
\hline Space heating & 5.11 & 0.00 & 3.21 & 0.00 & 0.00 & 0.00 & $\mathbf{8 . 3 1}$ \\
\hline Space cooling & 3.62 & 0.00 & 0.00 & 0.00 & 0.00 & 0.00 & $\mathbf{3 . 6 2}$ \\
\hline $\begin{array}{l}\text { Animal feed } \\
\text { preparation }\end{array}$ & 0.00 & 0.00 & 11.69 & 0.00 & 0.00 & 0.00 & $\mathbf{1 1 . 6 9}$ \\
\hline Total & $\mathbf{9 7 . 4 8}$ & $\mathbf{1 3 . 3 5}$ & $\mathbf{5 6 . 3 2}$ & $\mathbf{1 2 . 6 6}$ & $\mathbf{1 1 4 . 8 1}$ & $\mathbf{0 . 3 6}$ & $\mathbf{2 9 4 . 9 9}$ \\
\hline
\end{tabular}

Table 3 Fuel-wise Demand for Base Year

\subsection{Scenario Results}

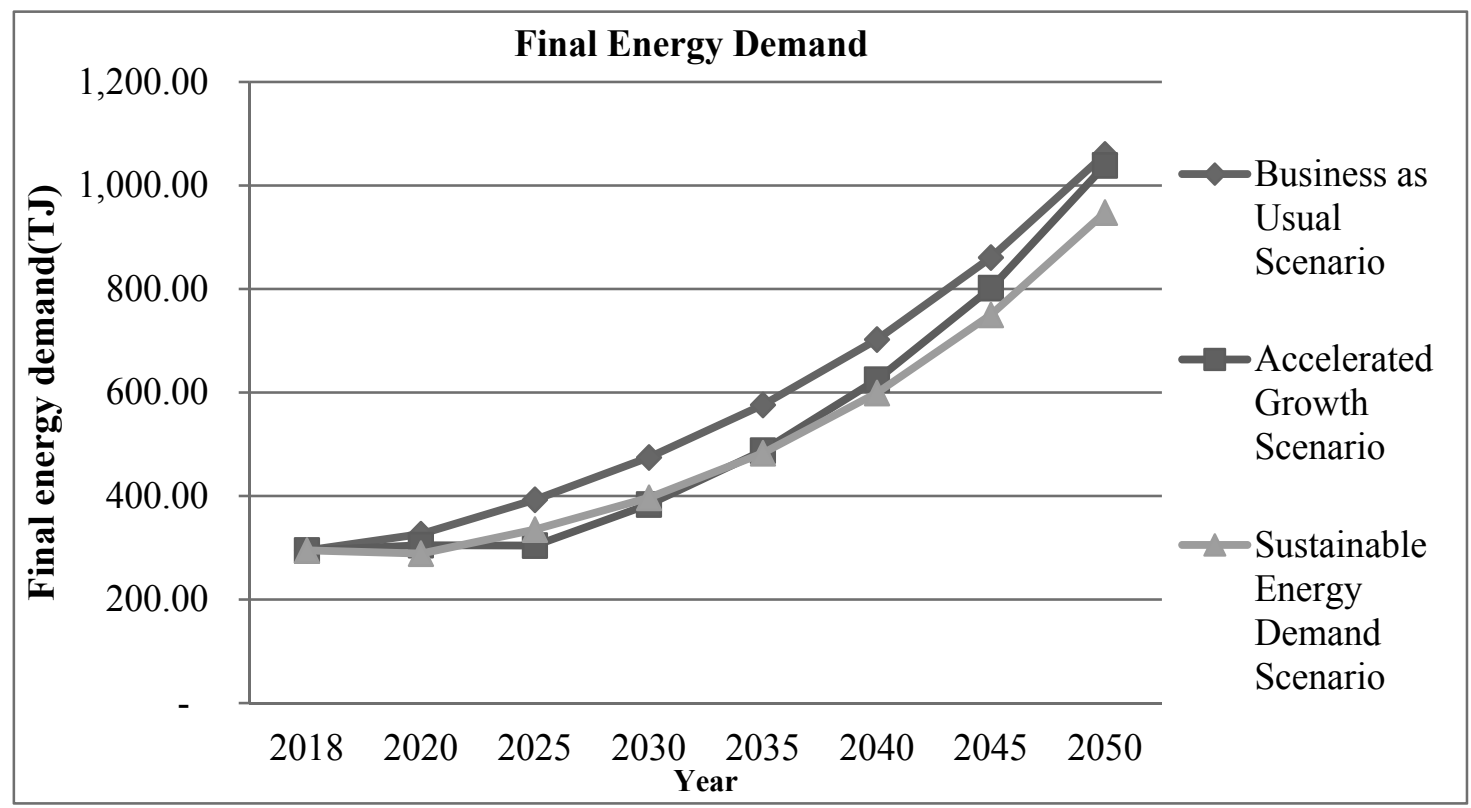

Figure 6 Final Energy Demand

Fig. 6 compares final energy demand of all three scenarios. Energy demands are highest in BAU scenario in year 2050 than another two scenarios. This is due to highly dependent on traditional fuels. Energy demand is lowest in AGS scenario as it considered gradual phase out of traditional as well as fossil fuel the year 2025. Annual electricity consumption per capita in BAU Scenario is $2430 \mathrm{KWh}$ for the year 2030, based on the multi-tier matrix for electricity consumption "Beyond Connection: Energy Access Redefined" [13], BAU falls on tier-4 (1250-3000) KWh). After 
transition of all traditional and fossil fuel to electricity and solar, annual electricity consumption per household is 3840 and $4698 \mathrm{KWh}$ in SED and AGS respectively lies in between $3000 \mathrm{KWh}$, thus lies on tier-5.

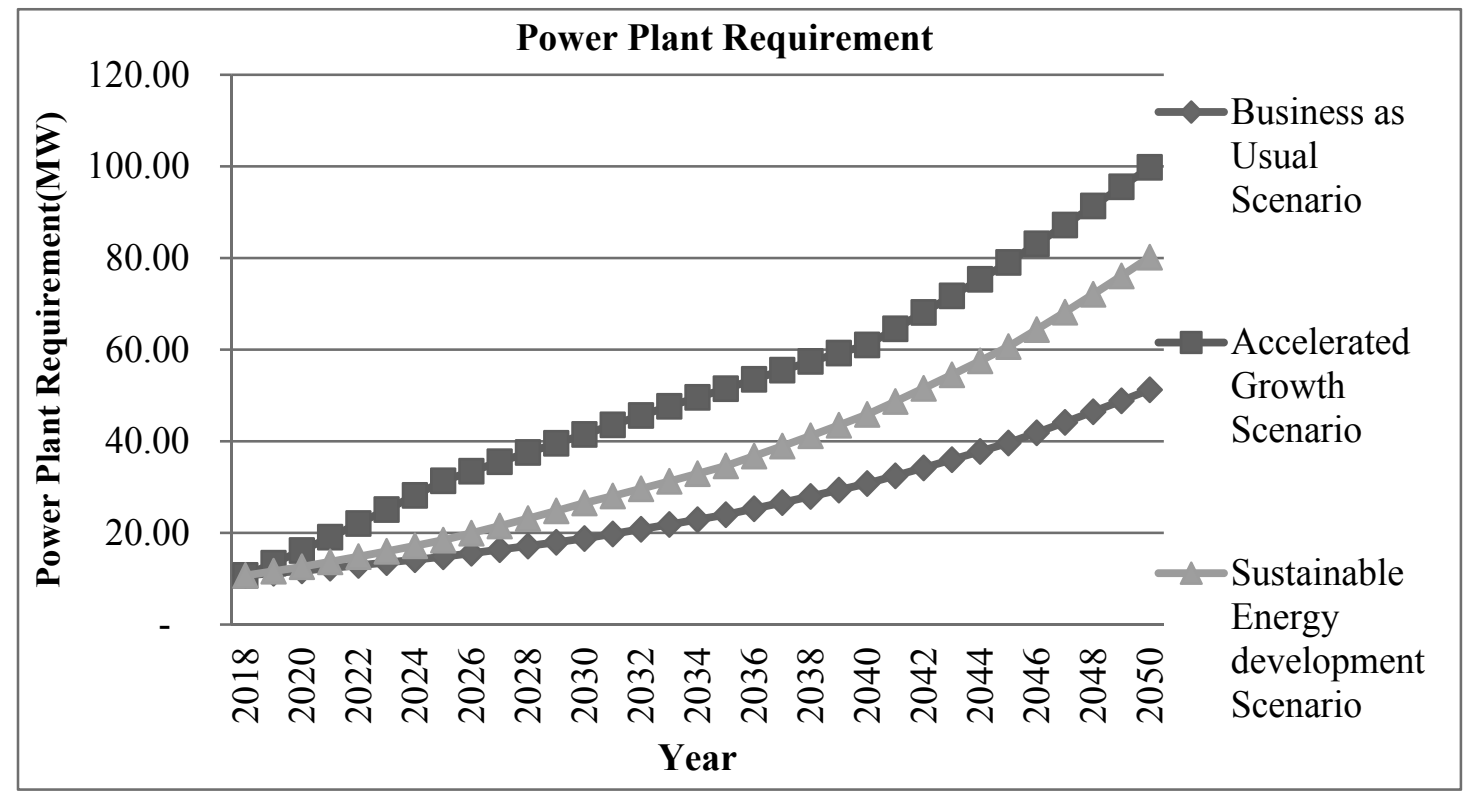

Fig 7 Power Plant Requirement

Fig. 7 shows total power plant requirements in each scenario. The power plant requirement is highest in AGC scenario and lowest in BAU scenario which will be about 51MW, 100MW and 80MW in BAU, AGS and SED scenarios respectively.

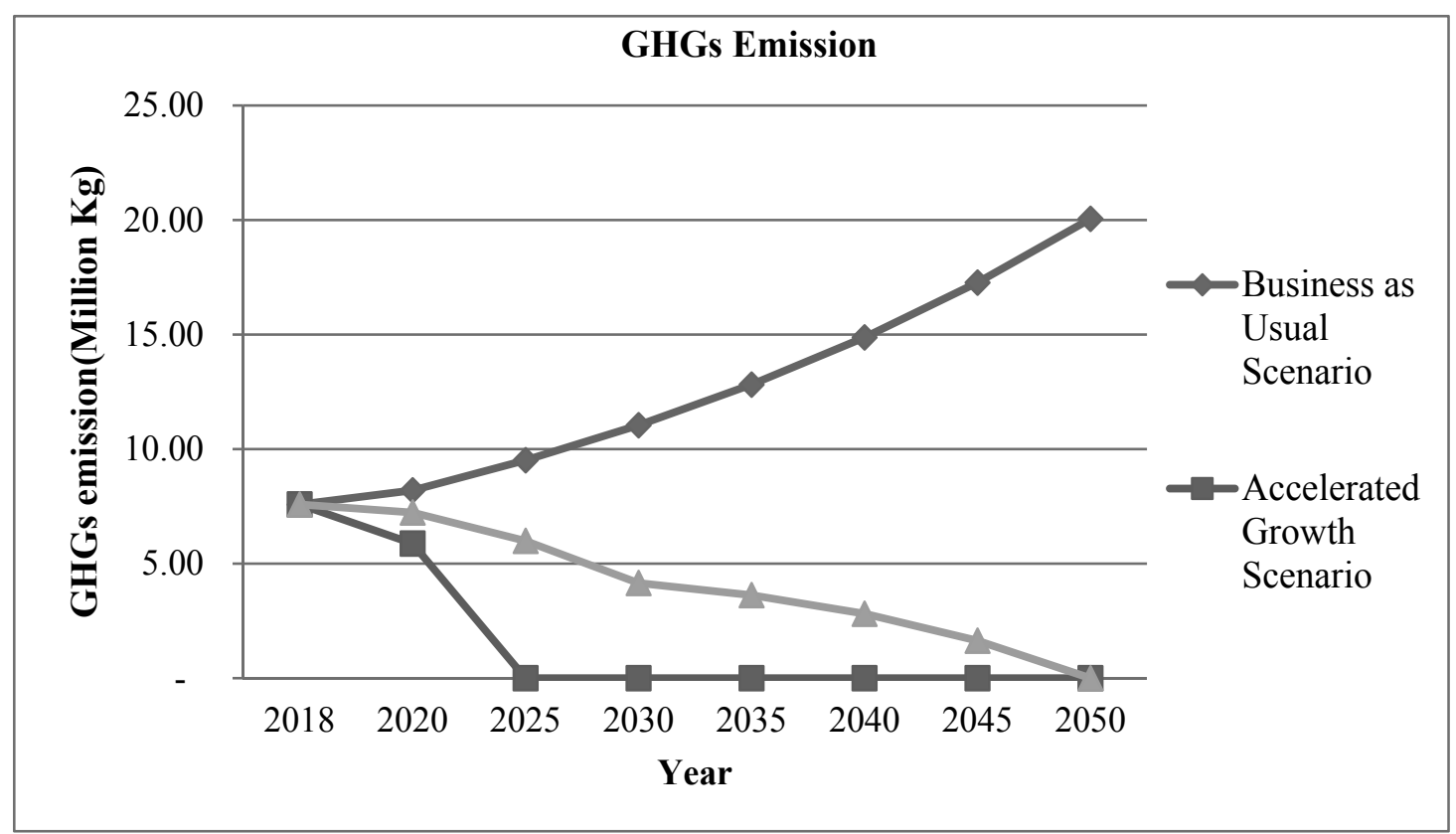

Fig 8 GHGs Emission 
Fig. 8 shows the GHGs emissions for each scenario. It can be seen that GHGs emission in BAU scenario grows with the rate of $3.08 \%$, whereas in SED and AGS scenarios emission will gradually reduce to negligible by the year 2050 and 2025 respectively. The per capita GHG emission in BAU scenario is about $84 \mathrm{~kg}$.

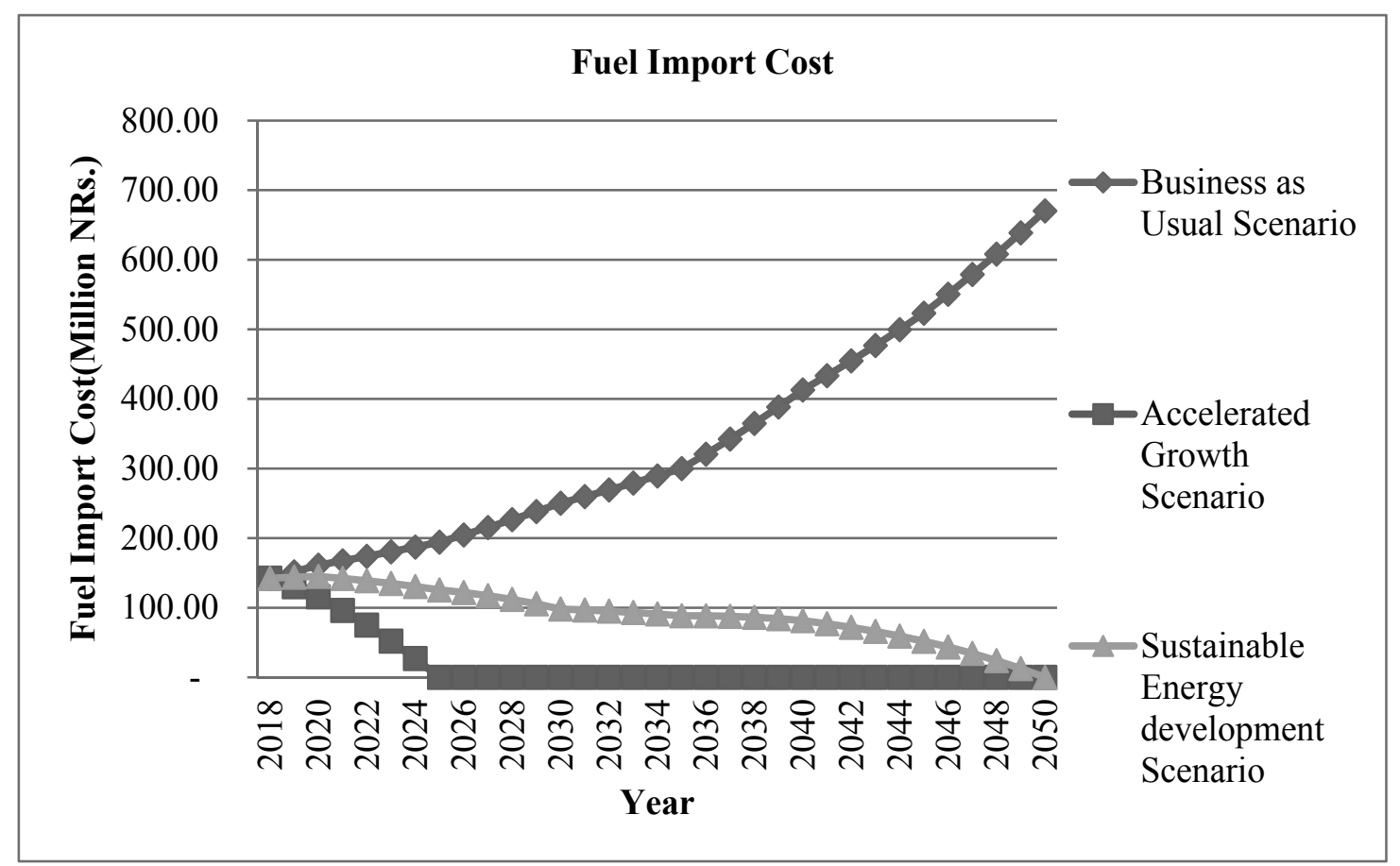

Fig 9 Fuel Import Cost

Fig. 9 shows the fuel import cost for LPG import. Total fuel import cost in base year is NRs. 142 million. In BAU scenario fuel import cost increases at the rate of $4.96 \%$ annually and reach NRs 670.32 million in 2050. Whereas in SED scenario fuel import cost will be negligible year 2050, whereas in AGS scenario, fuel import cost is negligible in year 2025 and will be phase out with grid electricity and rooftop solar PV .

\section{Marginal Abatement Cost (MAC)}

Marginal abatement cost (MAC) depicts investment required to reduce the emission from that of business as usual level, and is generally expressed in cost per $\mathrm{kg}$ of $\mathrm{CO} 2$ equivalent. Fig.10shows the MAC for GHG emission reduction for two policy scenarios. AGS scenario shows gradual decreasing trend of MAC. MAC is very high at early stage at around NRs. 170 per kg of CO2-e abated. This is due to high investment in hydropower plant and rooftop solar PV as these are very cost intensive in terms of capital cost. The higher capital cost for power plant increases MAC by highest factor. But once the generation technology and end use devices is there, MAC reduces gradually to about NRs. minus three (3) in year 2040 when electric technologies will be takeover other non-electric technologies. Thus we can see that, electrification is most appropriate practical energy scenario. Moreover having a hydro power plant and diversification in generation system with solar PV, it gives the assurance of reliability and energy security and other risks. 


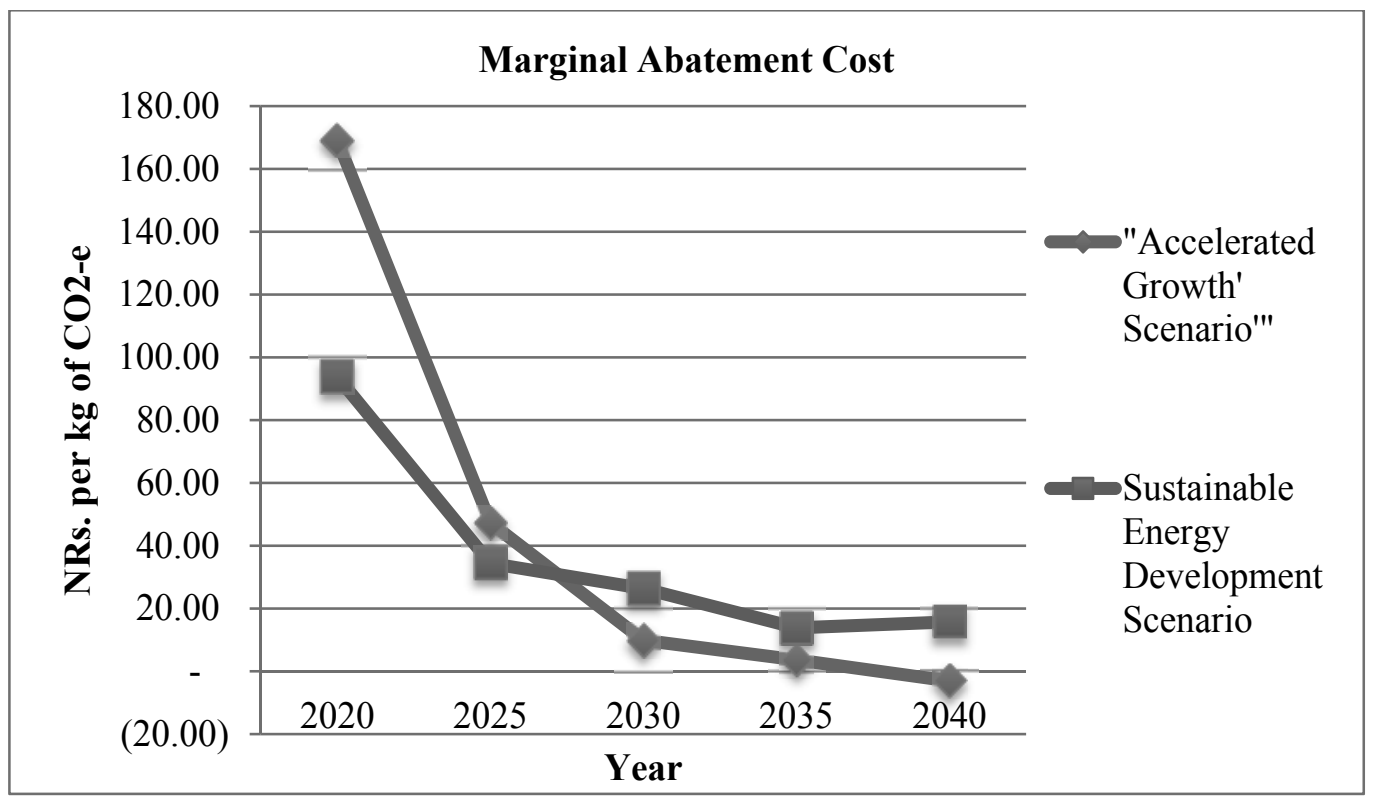

Fig 10 Marginal Abatement Cost

\section{Cost-Benefit Summary Analysis}

The most important part of cost benefit analysis is net present value (NPV), which is one of the criteria to select the scenario. The NPV in AGS and SED scenarios are lower than BAU, which means that, both of the scenarios are economically viable. In AGS and SED scenario GHG saving is achieved. Form NPV value, as compare to AGS, it is found that SED scenario is most economically viable with NPV value NRs.5847 million, though the co-benefit(like: higher economic growth, reduced trade deficit, energy mix of solar and hydro, reduction of GHG emission etc) in AGS scenario is higher as compare to SED . Therefore, AGS scenario stands out best amongst all scenarios. Cost \& Benefits is presented in Table 4.

\begin{tabular}{|l|c|c|c|}
\hline $\begin{array}{c}\text { Cumulative Costs \& Benefits: 2018- } \\
\text { 2050(NRs. Million) at 6\% discounted } \\
\text { Rate. }\end{array}$ & $\begin{array}{c}\text { Business as } \\
\text { Usual } \\
\text { Scenario }\end{array}$ & $\begin{array}{c}\text { Accelerated } \\
\text { Growth } \\
\text { Scenario }\end{array}$ & $\begin{array}{c}\text { Sustainable Energy } \\
\text { Development } \\
\text { Scenario }\end{array}$ \\
\hline Demand & 13.31 & 18.25 & 27.06 \\
\hline Residential sector & 13.31 & 18.25 & 27.06 \\
\hline Transformation & $2,379.00$ & $5,542.71$ & $3,976.75$ \\
\hline Transmission and Distribution & - & - & - \\
\hline Grid electricity & $2,379.00$ & $3,451.08$ & $3,976.75$ \\
\hline Solar & 0.00 & $2,091.63$ & 0.00 \\
\hline Resources & $5,156.00$ & 765.49 & $1,804.16$ \\
\hline Production & $1,298.80$ & 215.95 & 197.60 \\
\hline Imports & $3,857.21$ & 549.54 & $1,606.56$ \\
\hline Environmental Externalities & 84.13 & 14.64 & 39.07 \\
\hline Net Present Value & $7,632.45$ & $6,341.10$ & $5,847.03$ \\
\hline GHG Emissions (MillionTonnesCO2e) & 0.43 & 0.03 & 0.13 \\
\hline
\end{tabular}

Table 4 Cumulative Costs \& Benefits 


\section{Conclusion}

The energy system and its development prospects are fundamental to every economic activity. Thus, a sufficient energy supply is a precondition for economic development. To meet sustainable development various indicators have been derived to evaluate each scenario. According to evaluation results, the current pattern of energy demand would put huge pressure not only in energy requirement but also national economy. An effective policy is the imperative requirement in current situation. The policy should be driven by strategies for utilization indigenous renewable resources instead of importing petroleum products. The effective measure could contribute to the transformation of the energy system towards a more sustainable development meeting the international and national commitment of Nepal towards climate change.

\section{Recommendations}

A study has some shortcomings and limitations due to various factors. During the study certain assumptions were made. With the reference to this study, further studies could be done. The survey is based on pure geographic sampling bound by administrative boundaries. Pure consumption analysis can yield more descriptive energy consumption pattern and effect of energy transition. Others sectors like commercial, transportation, etc. can be studied in the area. The emission from other energy sectors as well as non energy sectors such as enteric fermentation can be undertaken as further study. Also its impact to the human health, environment and agriculture can be analysed.

\section{Acknowledgments}

The authors are grateful to Stockholm Environment Institute for providing the Long range Energy Alternatives Planning System (LEAP) tool for free of cost. 


\section{Reference}

1. G. Leach, "The energy transition. Energy Policy, pp.761-64.," 1993.

2. S. \&. J. L. Pachauri, "The household energy transition in India and China. Energy Policy, pp.4022- 4035.," 2008.

3. UNDESA, "World Urbanization Prospects: 2014 Revision. New York: United Nations Department of Economic and Social Affairs. http://esa.un.org/unpd/wup/FinalReport/WUP2014-Report.pdf," 2014.

4. B. Municipality, "Bhaktapur Municipality," 2018. [Online]. Available: http://bhaktapurmun.gov.np/en.

5. A. G. A. K. K. \&. P. S. Shrestha, " Study of Current Energy Consumption of Dhulikhel Municipality. Proceedings of the International Symposium on Current Research in Hydraulic Turbines .," 2016.

6. AEPC, "District Climate and Energy Plan Bhaktapur District," 2014.

7. U. S. \&. N. A. Rajbhandari, "Energy Consumption and Scenario Analysis of Residential Sector Using Optimization Model - A Case of Kathmandu Valley. Proceedings of IOE Graduate Conference, 476-483.," 2014.

8. B. Panthi, "Energy and Emission Analysis Of Residential Sector: A Case Study For Reshunga Municipality In Nepal," 2018.

9. R. V. \&. M. D. W. Krejice, "Determing Sample Size for Research Avtivities.Educational and Psychological Measurement, 607-610.," 1970.

10. NRB, "Household Budget Survey. Kathmandu: Nepal Rastra Bank.," 2008.

11. S. R. \&. S. R. M. Shakya, "Transport sector electrification in a hydropower resource rich developing country: Energy security, environmental and climate change co-benefits. Energy for Sustainable Development" , 15, 147-159.," 2011.

12. ADB, "Asian Development Outlook. Asian Development Bank.," 2018.

13. W. Bank, "Multi-tier matrix for electricity consumption" Beyond Connection: Energy Access Redefined," 2015.

14. B. Reddy, "Urban Energy System. New Delhi, India: Concept Publishing company.," 1998.

15. E. L. D. M. V. Hache, "Beyond average energy consumption in the French residential housing market: a household classification approach. Energy Policy 107, 82-95.," 2017.

16. M.-L. Nauleau, "Free-riding on tax credits for home insulation in France: an econometric assessment using panel data. Energy Econ. 46, 78-92.," 2014. 